\title{
PEMANFAATAN CONSTRUCTED WETLAND SEBAGAI BAGIAN DARI RANCANGAN LANSEKAP RUANG PUBLIK YANG BERWAWASAN EKOLOGIS STUDI KASUS HOUTAN PARK CHINA
}

\author{
Barito Adi Buldan Rayaganda Rito \\ Universitas Islam Indonesia, Jalan Kaliurang KM 14,5, Sleman, DIY \\ Email : barito_mail06@yahoo.com
}

\begin{abstract}
Abstrak
Kebutuhan akan air bersih merupakan salah satu permasalahan lingkungan yang sering terjadi. Hal ini sejalan dengan kebutuhan akan kualitas lingkungan yang lebih baik, khususnya dalam kasus ruang luar atau lansekap. Lansekap berbasis suasana air merupakan satu bentuk ruang luar yang memiliki keistimewaan sekaligus tantangan, terkait kualitas air dan model pembersihannya. Dari berbagai metode pembersihan air yang ada, Constructed Wetland merupakan suatu bentuk pembersihan kondisi air alamiah dengan meniru wetland alamiah baik dari segi struktur pewadahannya maupun vegetasi - vegetasi yang digunakan.

Paper ini bertujuan untuk mengetahui penerapan upaya pembersihan air secara alami menggunakan metode constructed wetland, dan melihat pemanfaatan metode ini dalam integrasinya dengan rancangan lansekap. Penelitian bersifat kualitatif dengan Metode penelitian deskriptif, melalui studi literature dan kasus di Houtan Park, China.

Dari hasil penelitian ini disimpulkan bahwa sebagai pilihan metode pembersihan air secara alamiah, ruang dan suasana yang tercipta dari sistem ini berpotensi untuk dikembangkan menjadi bagian dari konsep rancangan lansekap. Dalam studi kasus di Houtan park, Shanghai, China, constructed wetland tidak hanya dimanfaatkan sebagai sarana pembersihan air, namun menjadi bagian dari area lansekap ruang publik yang dapat dinikmati dan membuat pengunjung lebih dekat dengan alam dan lingkungan yang berkualitas.
\end{abstract}

Kata Kunci : Constructed Wetland, Lansekap, Houtan Park China

\begin{abstract}
The needs of clean water is becoming common in recent era. Its Parallel with the needs of better quality of livable environment, specifically in outdoor spaces or landscape area. Water based landscape is commonly known by its beauty along with its downside regarding the water cleanse method. Among available methods, utilizing constructed wetland considered as a natural cleanse method, by applying the natural principles of wetland, from its structures and vegetations.

This paper aims to examine further about the application of natural water cleanse method of constructed wetland and to obtain further understanding of how to integrate it with landscape design. This research is qualitative, with descriptive method through the study reference and case of Houtan park, China.

In conclusion, the natural water cleanse method has prospective usage to be integrated with of landscape design concept. In Houtan Park case, along with purifying water, the wetland area is designed to be part of public space and circulation, which provide the enjoyable spaces and brings people closer with nature
\end{abstract}

Keywords : Constructed Wetland, Landscape, Houtan Park China 


\section{PENDAHULUAN}

Peledakan jumlah penduduk di daerah urban dewasa ini secara tidak langsung berimbas pada berbagai aspek salah satunya ialah ketersediaan air bersih dan sanitasi (UN Water Decade Program, n.d.). Dunia ini membutuhkan solusi berkelanjutan (sustainable) untuk mengatasi kebutuhan air bersih dan juga untuk mengelola air limbah yang umumnya menjadi sumber utama pencemaran sumber air bersih. mencemari sumber air itu sendiri (Stokman, 2008). Dalam sudut pandang kebutuhan akan layanan ekosistem (ecosystem service), studi - studi menunjukkan bahwa ada keterkaitan antara layanan yang spesifik dari ekosistem, berupa relasi antara karakter biofisik dari lansekap, fungsi, layanan, keuntungan dan nilai - nilai bagi masyarakat (Müller \& Willemen, 2010). Layanan ekosistem terkait kebutuhan air bersih dengan dampak yang berkaitan dengan aspek lain dapat diupayakan melalui integrasi constructed wetlands dengan perancangan tata lansekap.

Wetland merupakan area-area transisi antara tanah dan air, wetland alamiah mencakup antara lain, rawa-rawa, padang rumput basah, lahan yang terkena pasang surut, dataran banjir, dan lahan basah di sepanjang saluran sungai (UN HABITAT, 2008). Sedangkan Constructed wetland adalah lahan basah buatan, dengan fungsi pemurnian air limbah dengan menggunakan fisik, kimia dan metode biologi dalam sebuah eco-system, memanfaatkan proses filtrasi, adsorpsi, sedimentasi, pertukaran ion dan penguraian mikroba (Tian, 2011). Temuan pertama dengan menggunakan macrophytes dalam constructed wetland untuk pengolahan wastewater diperkenalkan oleh Käthe Seidel dari Jerman pada tahun 1950s, dengan metode yang kita sekarang kenal dengan sebutan horizontal sub-surface flow. Reinhold Kickuth, membuat perbaikan - perbaikan pada sistem ini, dan lambat laun metode ini dikenal luas di Eropa (Vymazal, 2005).

Dalam penyediaan ruang terbuka bagi masyarakat, dapat dipahami bahwa terdapat interaksi yang rumit antara pribadi, ekologi dan faktor spasial fisik dalam membentuk persepsi, evaluasi dan penggunaan ruang public di perkotaan (Irvine, Et al, 2009) dan (Wolch, Et al., 2014). Dalam rancangan lansekap berbasiskan wetland, Integrasinya bersama ruang public dapat membawa banyak keuntungan seperti secara ekologis dengan terurainya limbah, secara biologis dengan terpenuhinya tambahan oksigen bagi biota aquatic, secara ekonomi dengan menambah nilai dan daya Tarik suatu kawasan dan secara social dengan terciptanya lingkungan yang lebih baik serta nilai pendidikan yang didapat dari pengamatan dan penelitian (Tian, 2011). Dalam kasus komunitas di "Shahre Javan" di Iran, situasi urban kluster yang padat, memungkinkan pemanfaatan Constructed wetland berperan sebagai sistem pengolahan air yang tersentralisasi,bersamaan dengan penyediaan ruang terbuka hijau dan area rekreasi (ElZein, Et al, 2016) . 
Constructed wetland pernah diterapkan di negara dengan penduduk terpadat di dunia yaitu China tepatnya pada kasus daerah bekas industri di Houtan Park. Pada kasus tersebut Consctructed wetland tidak hanya dimanfaatkan sebagai sarana membersihkan air sungai yang tercemar sebanyak 634.000 galon hari, metode ini meningkatkan juga kualitas air dari kelas V (cocok untuk kontak manusia) ke kelas II (cocok untuk irigasi lanskap) dan hanya menggunakan proses biologis (Landscape performance series). Selain itu, penerapannya pada lansekap membuat taman Houtan menjadi ruang publik yang lebih dapat dinikmati.

Tujuan dari penelitian ini adalah:

1. Mengidentifikasi berbagai bentuk constructed wetland sebagai solusi yang berkelanjutan dalam pembersihan air di daerah urban.

2. Menganalisis penerapan constructed wetland dalam rancangan lansekap pada studi kasus di Houtan Park, Shanghai, China.

Manfaat dari penelitian ini adalah sebagai berikut:

1. Memberikan manfaat bagi peneliti dalam pengaplikasian ilmu, khususnya dalam perencanaan lansekap sebagai solusi pada masalah air bersih di daerah urban.

2. Menjadikan rekomendasi bagi pemerintah seluruh dunia dalam penataan lansekap yang tepat untuk mengurangi resiko kekurangan air bersih.

3. Dapat menjadi arahan bagi pengembangan kawasan lanskap daerah urban untuk mengurangi kasus kekurangan air bersih sekaligus membentuk public space di daerah urban.

\section{METODE PENELITIAN}

Penelitian ini berupa penelitian kualitatif dengan metode deskriptif terhadap studi kasus, Hasil akhirnya akan diperoleh pemahaman yang mendalam mengenai kasus tersebut dapat menjadi dasar bagi riset selanjutnya. Pengamatan dilakukan terhadap kasus di Houtan Park, Shanghai, China

\subsection{SEJARAH CONSTRUCTED WETLAND}

Penemuan pertama menggunakan tumbuhan di wetland dibangun untuk pengolahan air limbah dan diperkenalkan oleh Käthe Seidel di Jerman pada awal 1950-an, dengan metode yang dikenal sekarang sebagai aliran sub-permukaan horisontal. Reinhold Kickuth, penelitian lebih lanjut pada tahun-tahun berikutnya. Kedua penemu memperbaiki sistem ini dan mulai diperkenalkan secara luas (Vymazal, 2005).

Walaupun potensi penerapan teknologi lahan basah di negara berkembang sangat besar, tingkat adopsi teknologi lahan basah untuk pengolahan air limbah di negara-negara berjalan lambat. Telah 
diidentifikasi bahwa keterbatasan teknologi penerapan Constructed Wetland untuk pengolahan air limbah di negara berkembang adalah karena fakta bahwa mereka memiliki pengetahuan dan pengalaman terbatas dengan desain dan manajemen Constructed Wetland (UN HABITAT, 2008).

\subsection{DESAIN DASAR CONSTRUCTED WETLAND}

Wetland adalah area transisi antara tanah dan air. Wetland atau lahan basah meliputi berbagai lingkungan basah, termasuk rawa-rawa, padang rumput basah, lahan basah di daerah pasang surut, dataran banjir, dan lahan di tepi saluran sungai.

Lahan basah biasanya merupakan cekungan dangkal penuh dengan semacam substrat, biasanya tanah atau kerikil, dan ditanami dengan vegetasi yang memliki tingkat jenuh tinggi. Air mengalir di atas permukaan atau melalui substrat, dan dibuang di ujung lain melalui bendungan atau struktur lain yang mengontrol kedalaman air di lahan basah. Dalam pengaturan komponen ini, air yang diolah perlu mengalir di aliran rendah. Air merupakan salah satu bagian yang paling utama dari proses tersebut, sehingga sangat penting untuk menjaga tingkat air seperti yang direncanakan dengan pertimbangan mungkin mengubah faktor kekeringan tersebut, dan curah hujan (UN HABITAT, 2008).

\subsection{SISTEM CONSTRUCTED WETLAND}

Secara umum, Constructed Wetland berbeda dari pola aliran airnya, yang mencakup aliran air di permukaan atas, permukaan bawah (horizontal dan vertikal) dan hybrid atau kombinasi antara keduanya. Pendekatan lainnya dikenal sebagai floating Island atau pulau mengapung, di mana media tanam berupa wadah yang mengapung.

\subsubsection{Aliran Air Permukaan Bebas atau Surface Flow (SF)}

Surface Flow adalah keadaan dimana ketinggian air berada di atas permukaan tanah; terdapat vegetasi berakar dan di atas permukaan air terutama di atas tanah. Dari bentuk hidupnya, tanaman macrophytes mendominasi, sistem Surface Flow ini dapat dilakukan dengan menerapkannya secara spontan dan menggunnakan tanaman yang terendam.

\subsubsection{Sub-Surface Flow}

Sub-Surface Flow adalah sistem dimana tingkat air berada di bawah permukaan tanah; air mengalir pada lapisan tanah atau kerikil, dan akar tanaman menembus hingga di bawah lapisan tanah. 


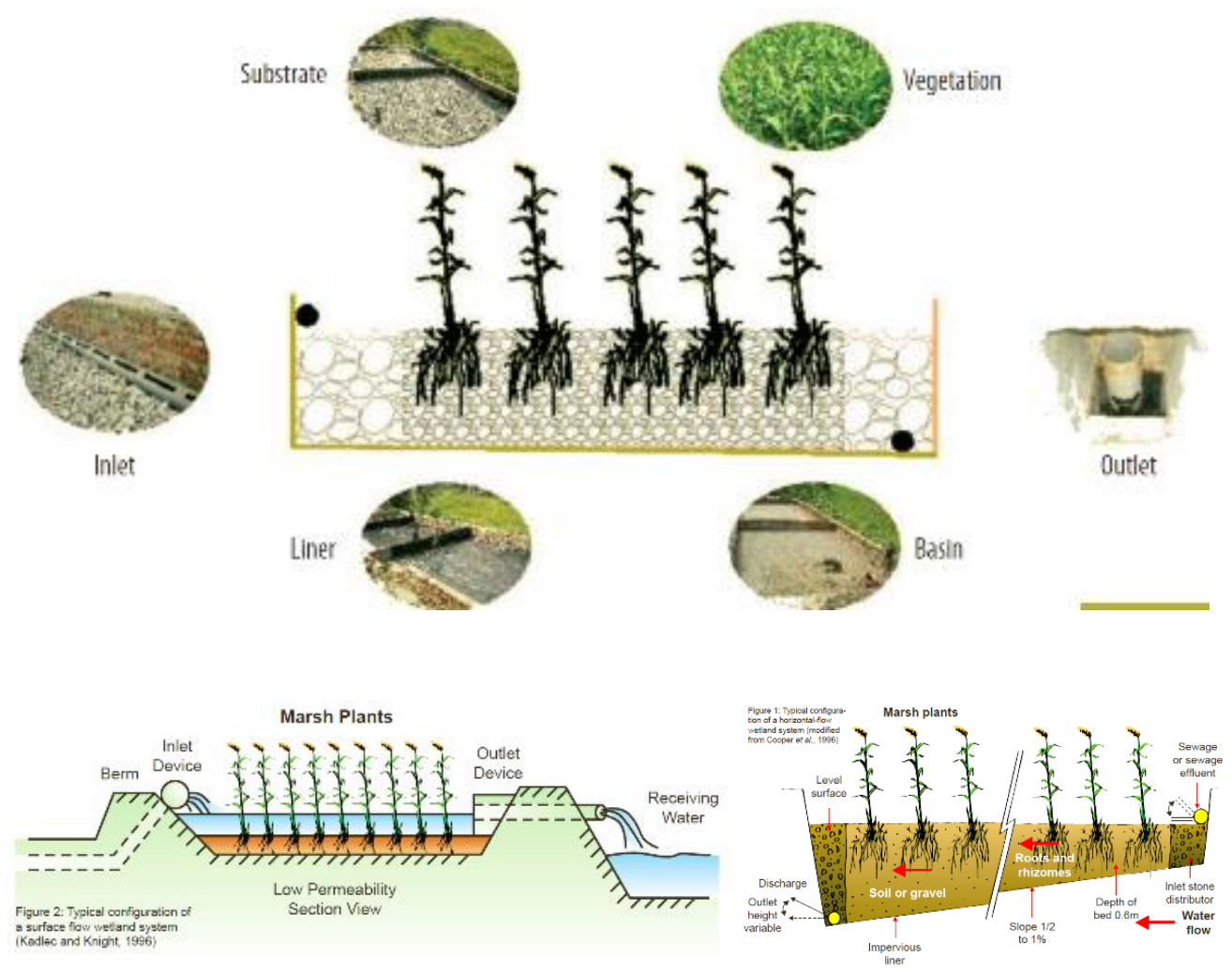

Gambar 1. Komponen-komponen wetland (Atas), Sistem Surface Flow (Bawah Kiri) dan Sub-Surface Flow (Bawah kanan)

Sumber: UN-HABITAT, Constructed Wetlands Manual (2008)

Terdapat empat metode sesuai dengan bagaimana air dapat menembus lapisan dalam tanah, yaitu:

1. Aliran Horizontal atau Horizontal Flow $(H F)$

Air limbah ditampung di dalam inlet dan mengalir perlahan melalui substrat berpori di bawah permukaan lapisan pada jalur horisontal sampai mencapai zona outlet. HF pada lahan basah dapat secara efektif menghilangkan polutan organik (TSS, BOD5 dan COD) dari air limbah. Hal tersebut disebabkan oleh transfer oksigen yang terbatas di dalam lahan basah, sehingga penghapusan nutrisi menjadi (terutama nitrogen) terbatas pula (UN HABITAT, 2008).

\section{Aliran Vertikal atau Vertical Flow (VF)}

VF pada lahan basah ditampung beberapa waktu di sekumpulan permukaan banjir yang besar. Cairan tersebut secara bertahap mengalir turun melalui lapisan tanah dan dikumpulkan oleh jaringan drainase di dasar. Air mengalir dengan bebas di laisan tanah dan memungkinkan udara untuk mengisi lapisan tanah tersebut. Dengan pembebanan intermiten, sistem ini memperoleh manfaat seperti: lebih besar kapasitas transfer oksigen sehingga nitrifikasi yang baik; hanya memerlukan ruang yang lebih kecil daripada sistem HF, dan efisien menghapus BOD5, COD dan patogen (UN HABITAT, 2008). 


\section{Constructed Wetland Kombinasi atau Hybrid}

Untuk mengatasi kelemahan pada kedua sistem sebelumnya, sistem Hybrid merupakan solusi yang lebih baik, yaitu dengan menggabungkan kedua metode sebelumnya (HF dan VF) secara berurutan (UN HABITAT, 2008).

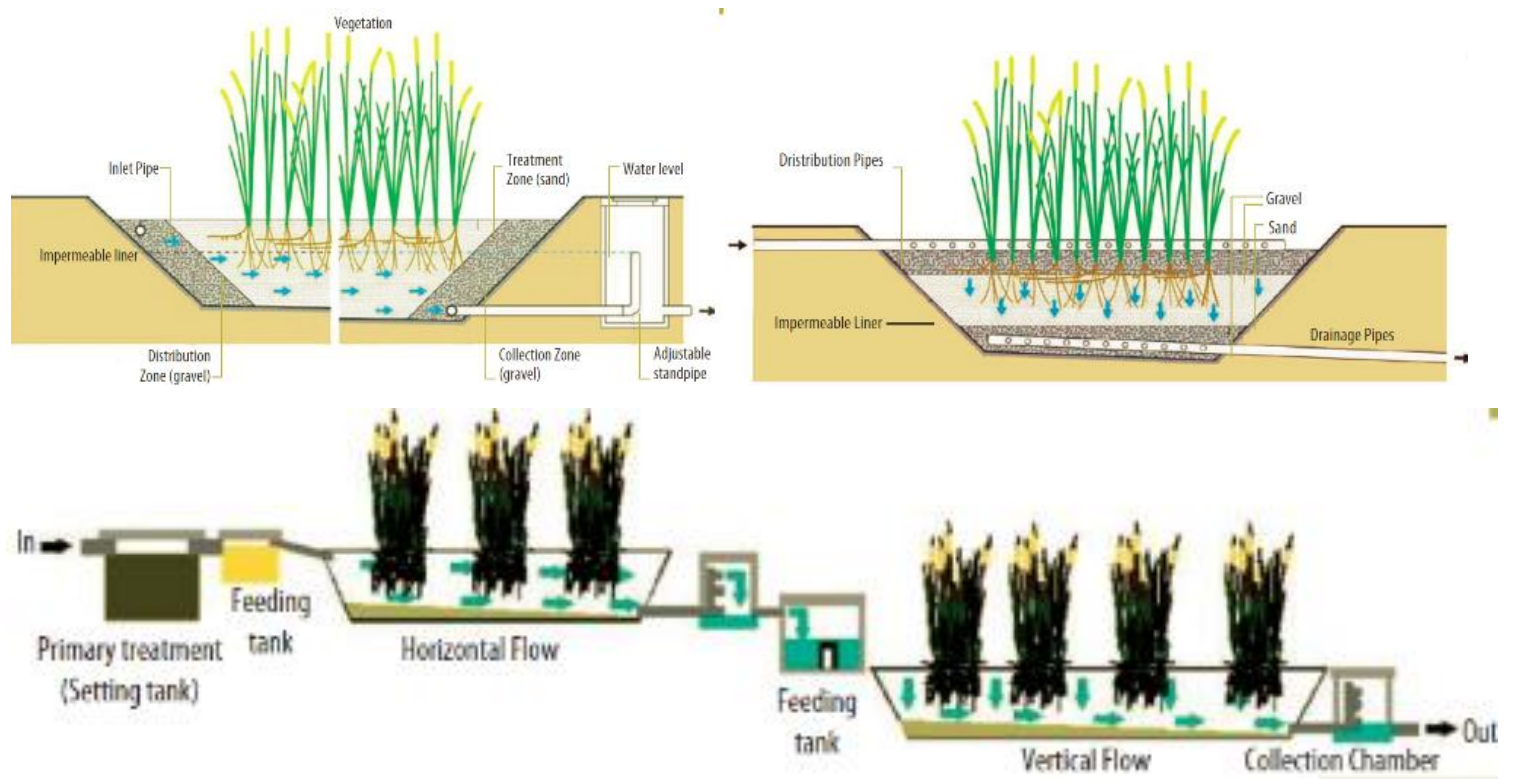

Gambar 2. Sistem Horizontal \& Vertical Flow (Atas), Sistem Hybrid (Bawah) Sumber: UN-HABITAT, Constructed Wetlands Manual (2008)

\section{Tanah Basah Mengapung atau Floating Island Wetland}

Metode ini untuk tanaman yang mengambang bebas, substrat sebagian besar adalah media ruang mengambang di mana tanaman tumbuh. Pengolahan Floating Wetland berbeda dari pengolahan lahan basah secara konvensional, dimana mikroba dan tumbuhan tumbuh di dalam platform mengambang, dan akar tumbuhan memanjang ke dalam air untuk mengambil nutrisi hidroponik. Sebaliknya, akar tanaman pada metode konvensional tumbuh ke dalam tanah dan tidak bersentuhan langsung dengan air yang kaya nutrisi. Akar dari tanaman yan mengambang juga menyediakan area tambahan untuk mendukung pertumbuhan mikroba (Stewart, et al., 2008). 


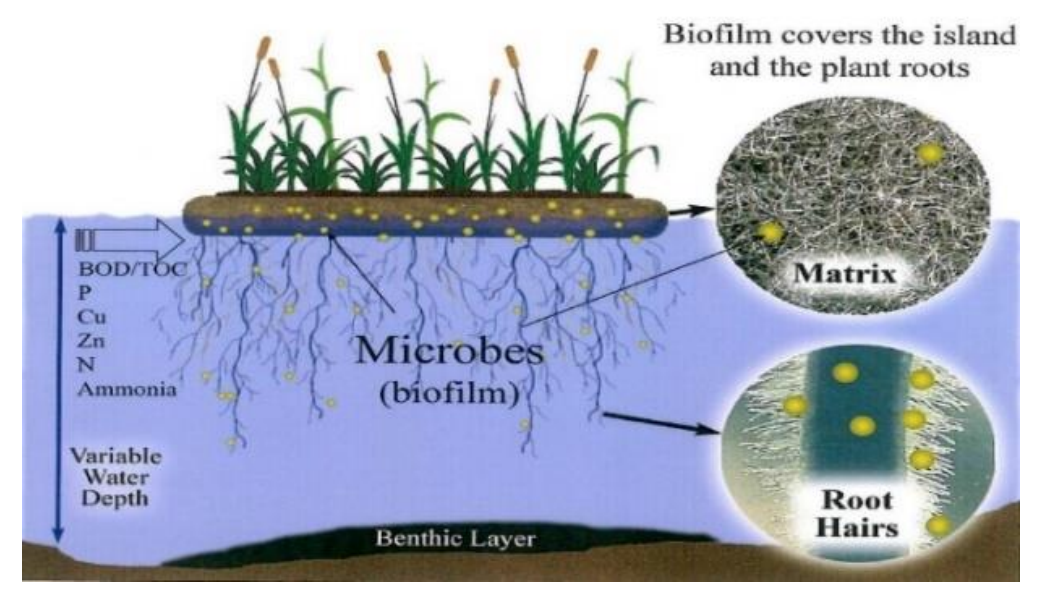

Gambar 3. Sistem Floating Wetland

Sumber : Floating Islands As an Alternative to Constructed Wetlands For Treatment of Excess Nutrients From Agricultural And Municipal Wastes, Stewart et al (2008)

\section{HASIL DAN PEMBAHASAN}

Houtan Park memiliki luas tanah sebesar 14 hektar dan terletak di sepanjang tepi Sungai Huangpu di Shanghai, China Yang kemudian direvitalisasi oleh arsitek lansekap yaitu Turenscape. Lahan tersebut sebelumnya dimiliki oleh pabrik baja dan galangan kapal, sehingga masih terdapat puing-puing bangunan industri di permukaannya maupun yang terkubur di dalam tanah dan dulunya sebagian besar lahan digunakan sebagai TPA dan lahan untuk menempatkan bahan-bahan industri. Sungai Huangpu yang dekat dengan lokasi sangat tercemar dengan peringkat nasional kualitas air dari Kelas Bawah V, kelas terendah pada skala I-V dan dianggap tidak aman untuk berenang, rekreasi dan tidak terdapat kehidupan air.

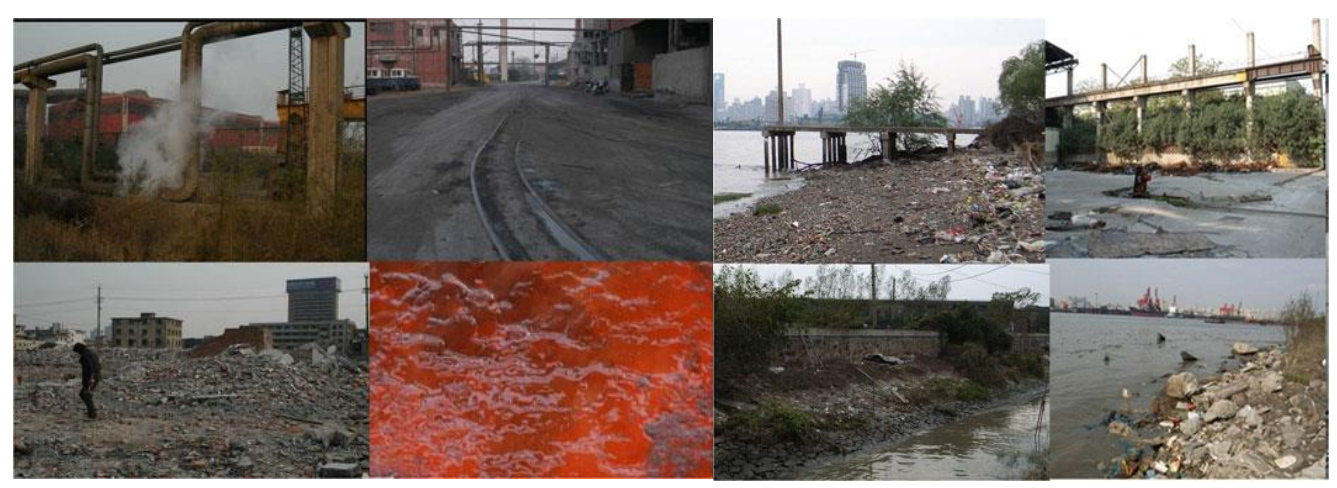

Gambar 4. Keadaan Houtan Park Sebelum Penataan

Sumber : https://www.asla.org/2010awards/006.html (diakses 1 November 2016)

Selain yang tecemar, pada site juga terdapat sebuah dinding setingi 6,7 meter yang digunakan untuk penanggulangan banjir, namun tembok tersebut sangat kaku dan terkesan tidak bernyawa. fluktuasi 
pasang surut harian setingggi 2.1 meter menciptakan garis pantai berlumpur dan saat ini tidak dapat diakses untuk umum. Sebuah dinding penahan konvensional akan terus membatasi aksesibilitas dan menghalangi penciptaan habitat di sepanjang tepi air.

\subsection{PENERAPAN CONSTRUCTED WETLAND PADA TATA LANSEKAP HOUTAN PARK, SHANGHAI, CHINA}

Manusia secara intrinsik terlibat dengan lingkungan hidup mereka untuk bertahan hidup. Mereka menggunakan lingkungan fisik untuk memenuhi kebutuhan fisik dan sosial mereka. Sementara lingkungan yang dibentuk oleh orang, orang terinspirasi dan dibentuk oleh lingkungan mereka juga. Dengan demikian, persepsi lingkungan atau lanskap telah menjadi bidang perhatian dari berbagai disiplin ilmu untuk memahami dan menjelaskan interaksi antara orang dan pengaturan fisik mereka (Kaymaz, 2012).

Lansekap disatu sisi menjadi bagian dari lingkungan alami-buatan yang selalu berinteraksi dengan manusia. Dengan fenomena ini, Kong Jian, melakukan pendekatan desain dengan memandang Houtan Park sebagai lanskap regenerative atas kerusakannya, dengan rancangan sistem hidup di mana infrastruktur ekologi dapat memberikan beberapa layanan bagi masyarakat dan alam dan pengolahan air ekologi baru dan metode pengendalian banjir. Peran arsitek lansekap dalam memahami tanah sebagai sistem hidup, untuk menjaga integritas dan identitas pemandangan alam dan budaya dan mengamankan ekosistem yang berkelanjutan (Kongjian, 2010)

Desain Houtan park sendiri mendapatkan pengakuan berupa Award of Excellency dari asosiasi arsitek lansekap amerika atau ASLA (American Society of Landscape Architect), karena desainnya yang sangat kuat dan sarat dengan pesan ekologis yang tepat bagi profesi lansekap.

\subsubsection{Konsep Dasar}

Strategi meregenerasi desain digunakan untuk mengubah site menjadi sistem hidup yang menawarkan servis ekologi, termasuk: produksi makanan, banjir, perawatan air, dan penciptaan habitat yang dikombinasikan dalam bentuk edukasi dan bentuk estetis.. 

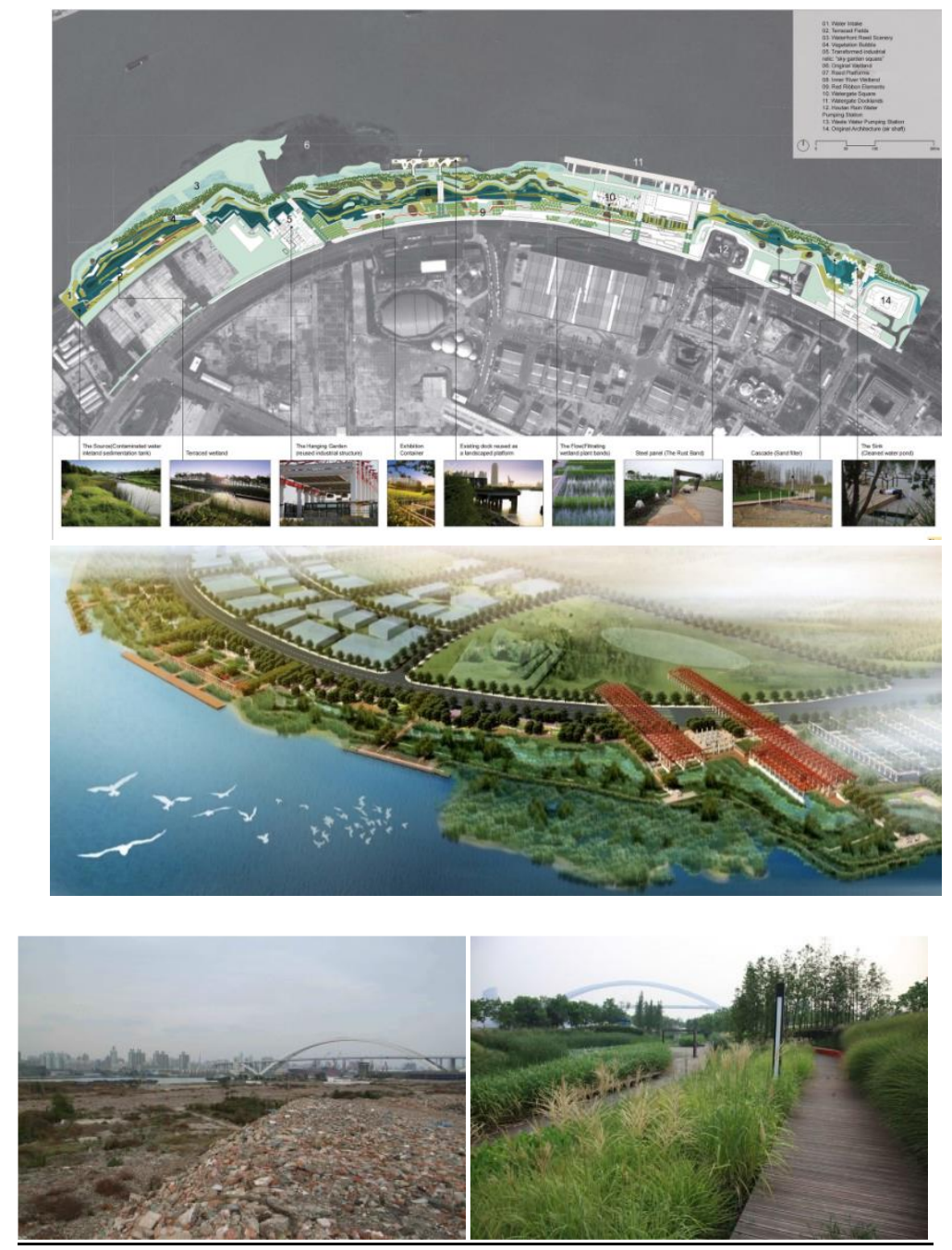

Gambar 5. Masterplan Houtan Park (Atas), Perbandingan Houtan Park Sebelum dan Setelah Pengembangan (Bawah)

Sumber : https://www.asla.org/2010awards/006.html (diakses 1 November 2016)

\subsubsection{Metode Pembersihan Air Berkelanjutan Menggunakan Constructed Wetland}

Melalui pusat taman, dirancang sebuah constructed wetland model Hybrid secara linear sepanjang 1,7 kilometer dan lebar 5-30 meter untuk menghidupkan kembali tepian air sebagai mesin hidup atau alami untuk mengolah kembali air yan tercemar dari Sungai Huangpu. Riam dan teras digunakan untuk mengoksidasi air yang kaya akan nutrisi, menghilangkan dan mempertahankan nutrisi, mengurangi sedimen-sedimen sekaligus menciptakan ciri-ciri air yang baik. Tanaman-tanaman wetland berbeda spesies dipilih dan didesain untuk menyerap polutan-polutan berbeda dari air. Tes lahan mengindikasi bahwa $2.400 \mathrm{~m}^{2}$ (500.000 galon) air perhari dapat diolah dari kualitas air Tingkat V menjadi Tingkat III. Air yang telah diolah dapat secara aman digunakan untuk seluruh kebutuhan Expo, dan menghemat setengah juta dollar AS dibanding menggunakan pengolahan air konvensional. Wetland juga berfungsi sebagai penyangga dan perlindungan dari banjir, antara 20 dan 1000 tahun tanggul penangkal banjir. Desain teras dari wetland mengurangi perbedaan elevasi antara kota dan 
sungai, sehingga orang dapat mencapai tepi sungai secara aman. Selain itu, Floodwall beton digantikan oleh susunan batu alam yang lebih ramah lingkungan dan memungkinkan spesies asli untuk tumbuh di sepanjang tepi sungai sambil melindungi garis pantai dari erosi.
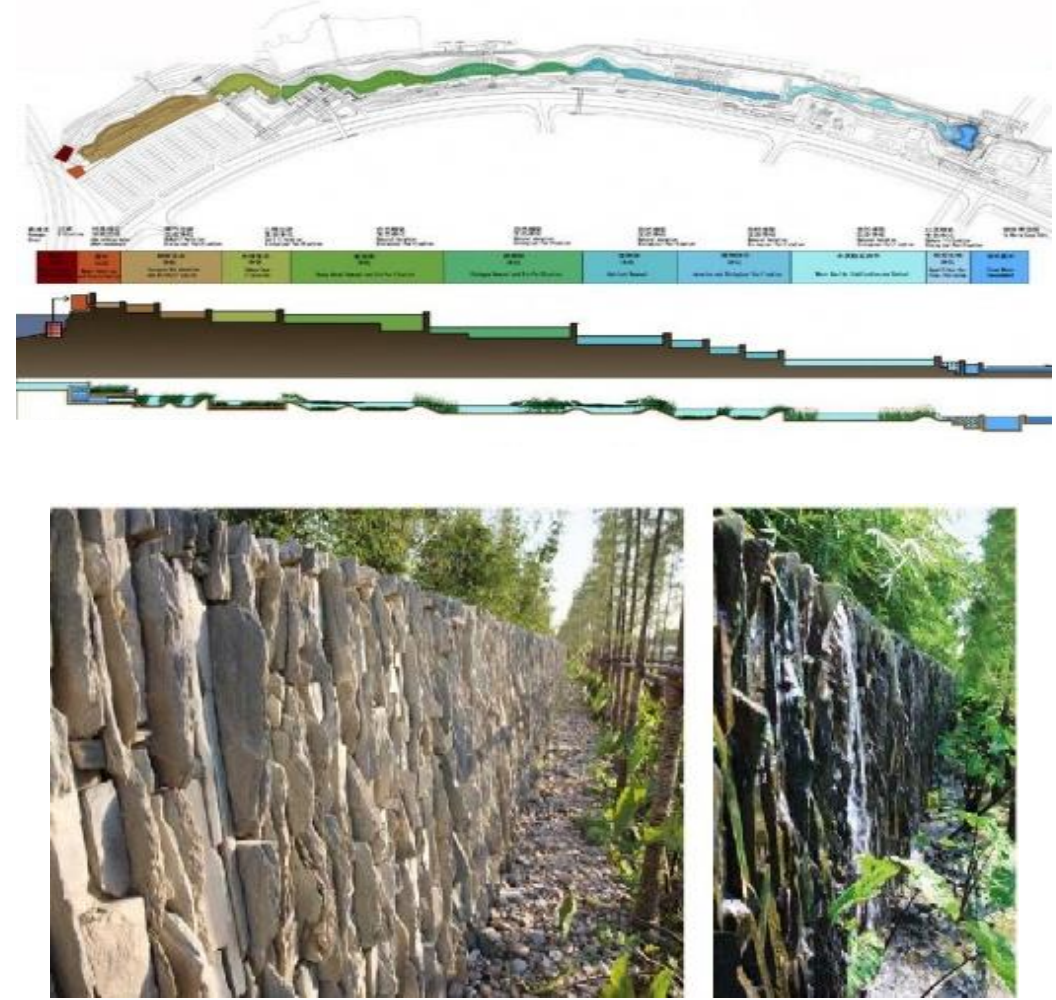

Gambar 6. Sistem Pengolahan Air Pada Houtan Park

Sumber : https://www.asla.org/2010awards/006.html (diakses 1 November 2016)

\subsubsection{Edukasi Hijau dan Konsep Estetika}

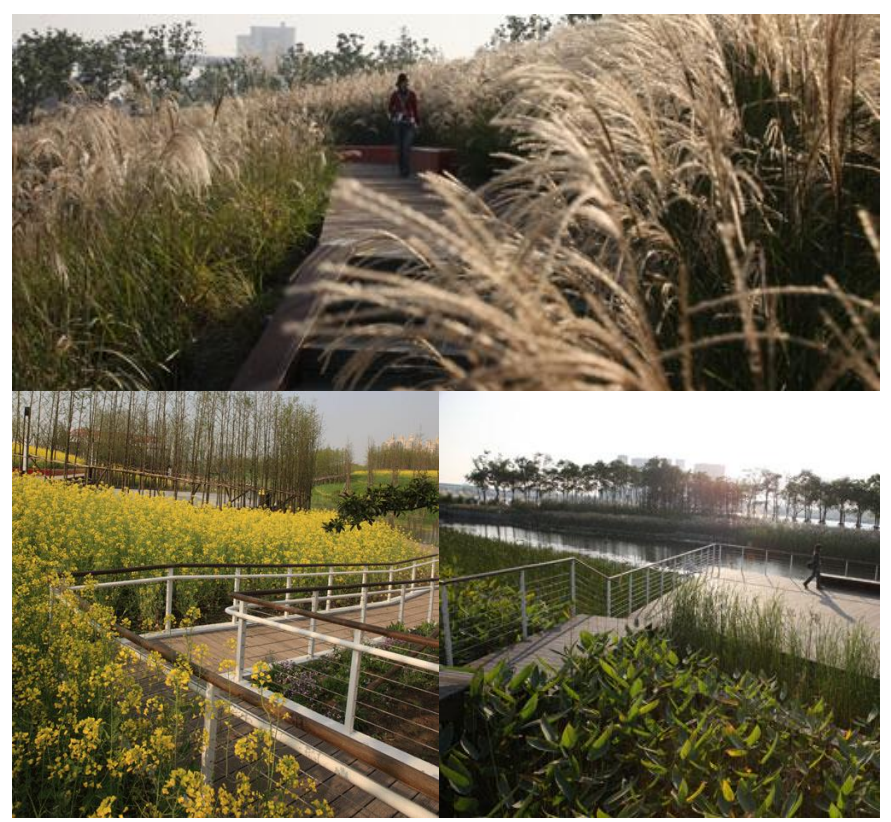




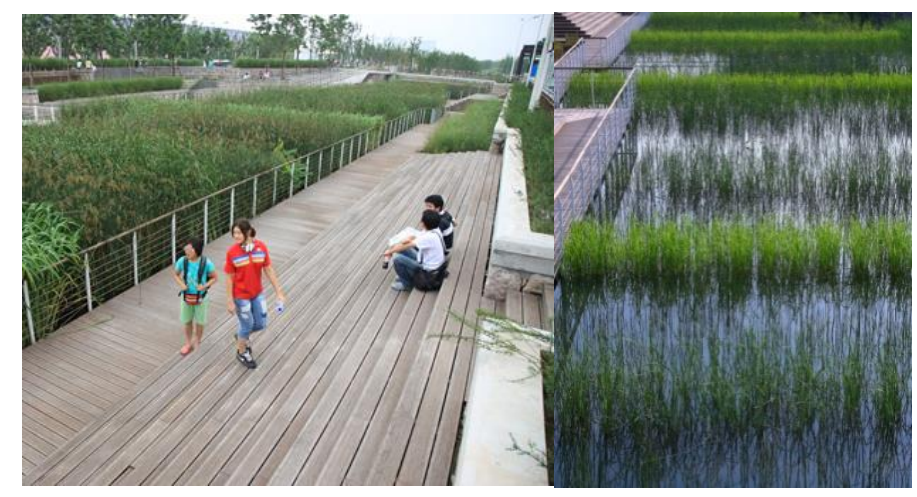

Gambar 7. Penataan Lingkungan Hijau Houtan Park

Sumber : https://www.asla.org/2010awards/006.html (diakses 1 November 2016)

Lansekap yang sudah pulih secara ekologi, pertanian di perkotaan, dan jiwa industri adalah tiga lapisan utama dari taman Houtan, tiga komponen tersebut disatukan oleh jalan kecil (pathway) dimana para pengunjung mendapat pengetahuan tentang infrastruktur hijau melalui area subur yang telah dipulihkan. Akses-akses untuk pejalan kaki disatukan oleh sebuah jalan memutar, selain itu terdapat jalan lurus yang membagi dua lahan basah dan jalan-jalan setapak yang mengarah melalui teras.

Terinspirasi dari lahan lansekap pertanian di China, teras-teras pada taman Houtan dibuat untuk memisahkan perbedaan ketinggian dari tepi sungai ke jalan sekitar 3-5 meter, dan untuk memperlambat aliran sungai yang mengalir langsung pada constructed wetland. Tanaman pertanian dan tanaman lahan basah dipilih untuk menciptakan pertanian urban yang memungkinkan warga sekitar menyaksikan perubahan musim: bunga emas di musim semi, bunga matahari di musim panas, aroma beras matang di musim gugur, dan clover hijau di musim dingin. Ini dapat memberi kesempatan bagi warga untuk belajar tentang pertanian dan peternakan dalam kota.

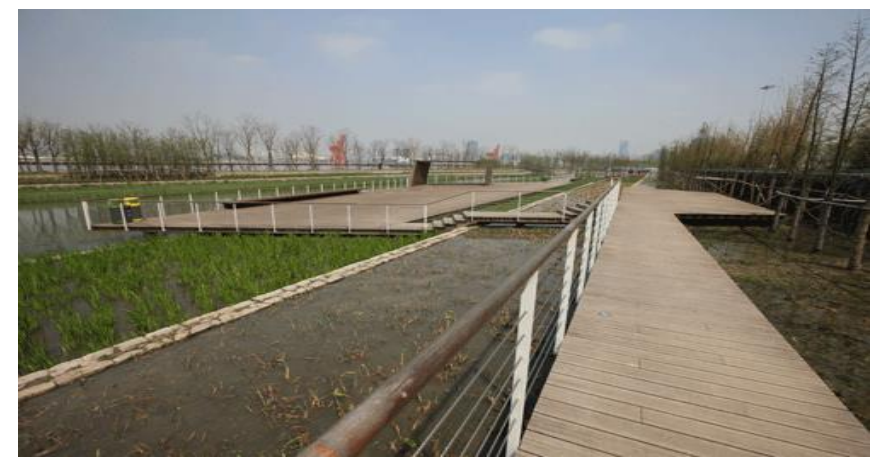




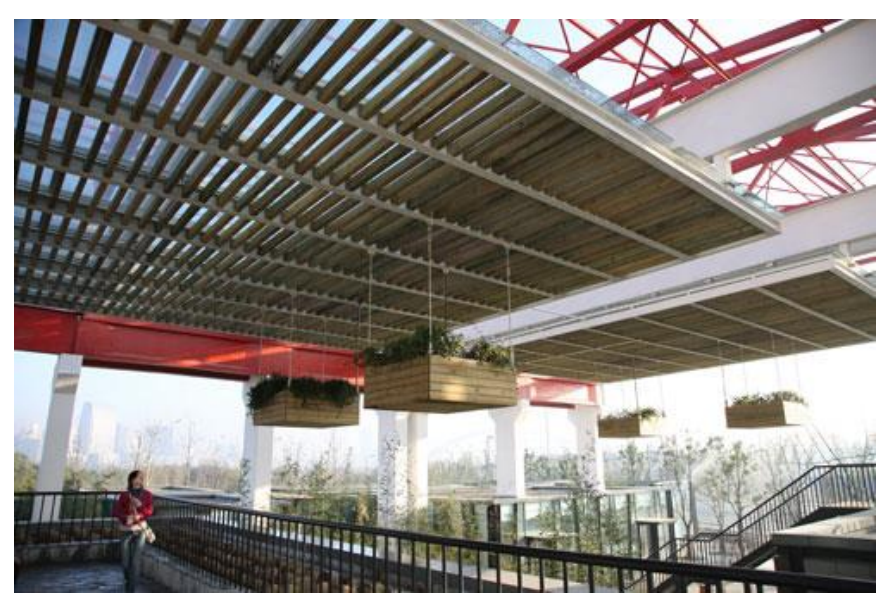

Gambar 8. Pedestrian Melebar Sebagai Simpul Taman (Atas), Taman yang Digantung

(Bawah)

Sumber : https://www.asla.org/2010awards/006.html (diakses 1 November 2016)

Teras-teras memperkaya pemandangan di sepanjang lahan basah dengan menciptakan ruang yang mendorong pengunjung untuk memasuki sistem hidup melalui koridor alami, juga untuk mengalami lansekap pertanian dan lahan basah secara langsung. Jalan, seperti kapiler dari spons, menyerap dan menarik orang untuk mengelilingi taman.

Terdapat beberapa platform dan 'wadah' tertutup yang dirancang sebagai simpul pada alur pejalan kaki, termasuk 'taman menggantung' yang merupakan transformasi dari struktur pabrik dan dermaga taman. Platform dan wadah ini diintegrasikan ke dalam alur pejalan kaki untuk menciptakan kesan terdapat titik yang lebih besar di mana kelompok-kelompok kecil dapat berkumpul. Rumpun bambu dan pohon Redwood Cina berfungsi sebagai layar di sepanjang jalan untuk memecah ruang dikelilingi oleh pohon-pohon yang digunakan untuk memamerkan seni modern dan peninggalan industri ditemukan di site.

\section{KESIMPULAN}

Constructed Wetland perlu dipertimbangkan sebagai pengelolaan air limbah karena telah terdapat banyak bukti kesuksesan metode tersebut dalam siklus berkelanjutan air yang tercemar. Banyak kelebihan yang dapat diperoleh dalam mengaplikasikan sistem ini di negara berkembang, khususnya jika diterapkan pada lahan yang terbuka. Selain itu, dapat terciptanya kesempatan untuk membawa warga agar dekat dengan alam. Temuan yang relevan terkait proses pemanfaatan constructed wetland yang terintegrasi dengan rancangan lansekap antara lain: 
1. Sistem yang paling berhasil untuk daerah-daerah luas dan kompleks dengan menggunakan pendekatan kombinasi (hybrid). Mengggabungkan HF dan VF akan memberikan hasil yang sempurna. Sementara pada skala kecil, sudah cukup dengan menggunakan satu tipe saja.

2. Integrasi dari constructed wetland pada desain lansekap akan membawa dimensi baru pada area urban yang dapat membawa manusia untuk lebih dekat dengan alam, memberikan keuntungan yang luar biasa pada ekosistem dan habitat sekitar, selain itu juga dapat menjadi area rekreasi.integrasi dilakukan baik dengan memberikan akses pengunjung melewati area vegetasi constructed wetland, dengan variasi tanaman dan konsep pertanian, dan dengan menempatkan ruang public sedemikian rupa, sehingga memaksimalkan interaksi antara pengunjung dengan alam.

Pada kasus Houtan Park, menunjukkan bahwa sistem hidup di mana infrastruktur ekologi dapat menyediakan beberapa layanan bagi masyarakat, alam, ekologi baru pada pengolahan air, dan pengendalian banjir. Setelah didesain kembali, lanskap menjadi lebih produktif dan unik, yaitu terciptanya kesan kebangkitkan kenangan masa lalu dan masa depan pada peradaban ekologi, memberikan wadah kepada estetika baru berdasarkan pemeliharaan rendah dan lanskap kinerja tinggi.

\section{DAFTAR PUSTAKA}

ElZein, Z, Abdou A, and ElGawad A. I, (2016). Constructed wetland as a Sustainable Wastewater Treatment Method in Communities, Procedia Environmental Sciences, (34), pp.605-617.

Irvine, K N., Wright, P. D, Payne, S. R. Fuller, R. A, Painter, B, and Gaston, K. J, (2009) Green space, soundscape and urban sustainability: an interdisciplinary, empirical study, Local Environment: The International Journal of Justice and Sustainability, 14, pp. 155-172.

Kaymaz, I. C., (2012). Landscape Perception, in Landscape Planning, Dr. Murat Ozyavuz (Ed.), pp.251-276.

Kongjian Y, (2010), 'Landscape as a living system: Shanghai 2010 Expo Houtan Park', Architectural Journal, No. 7 , pp. 30-35.

Müller F., R. G. \& Willemen L., (2009) Ecosystem Services, in the Landscape Scale: The Need for Integrative Approches, Landscape Online, pp. 1-11. 
Stokman, A. (2008). Water Purificative Landscapes - Constructed Ecologies and Contemporary Urbanism. Transforming with Water. Proceedings of the 45th World Congress of the International Federation of Landscape Architects IFLA 2008, pp. 51-61.

Stewart, Mulholland, Cunningham, Kania \& Österlund, (2008), Floating islands as an alternative to constructed wetlands for treatment of excess nutrients from agricultural and municipal wastes - results of laboratory-scale tests, Land Contamination \& Reclamation, pp.25-33.

Tian,M. (2011). Application of Constructed Wetland Technology in Urban Landscape Designs, Advanced Materials Research Vols. 211-212, pp. 939-943.

UN-HABITAT. (2008). Constructed Wetlands Manual. (Vol. 978-92-1-131963-7) UN-HABITAT Water for Asian Cities Programme.

UN-Water Decade Programme on Advocacy and Communication (UNW-DPAC). (n.d.), Water and cities facts and figures.(2010).

Vymazal, J. (2005). Horizontal sub-surface flow and hybrid constructed wetlands systems for wastewater treatment. In Ecological Engineering, (25), pp.478-490.

Wolch, J. R, Byrne J, and Newell, J. P, (2014). Urban green space, public health, and environmental justice: The challenge of making cities 'just green enough,Landscape and Urban Planning, (125) pp. 234-244.

www.asla.org/2010awards/006.html [Accessed 1 November 2016]

www.landscapeperformance.org/case-study-briefs/shanghai-houtan-park [Accessed 1 November 2016] 